\title{
A Study of the Needs for Learning Thai language and Culture of Japanese Students Studying Thai Language at the Faculty of Education, Chiang Mai University
}

\author{
Boonrawd Chotivachira \\ Faculty of Education, Chiang Mai University, Thailand
}

\begin{abstract}
For a long period of time, Faculty of Education, Chiang Mai University has offered the study program on Thai language and culture program for foreign students and foreigners interested in studying Thai language and culture. Every year, there are exchange Japanese students who are interested to study Thai language and culture there. The purpose of this research was to study the needs of Japanese students who study Thai language and culture at Chiang Mai University. The sample used was specifically selected from Japanese students who study Thai language and culture. There are 46 students 23 whom studying at Kokushilkan University and 23 studying at Kanda University of International Studies. The tools used for data collection are questionnaires. The quantitative data were analyzed in terms of percentage, mean and standard deviation. It was found that the needs for learning Thai language and culture in all 7 parts were with 4.26 mean at very high level. The needs along descending order of the least 7 ones are the needs for 1) contents learning which was with 4.57 mean and at highest level, 2) reasoning in Thai language which was with 4.39 mean and at high level, 3) teaching and learning management which was with 4.31 mean and at high level, 4) learning support for Thai language and culture of students which was with 4.29 mean and at high level, 5) learning measurement and evaluation which was with 4.18 mean and at high level, 6) teaching and learning materials and equipment which was with 4.13 mean and at high level, and, 7) purpose of learning Thai language and culture which was with 3.98 mean and at high level.
\end{abstract}

Keywords: Needs for studying Thai language, Learning Thai language and culture, Japanese students

\section{Introduction}

Language is a tool used for communication. It is important for the society at the present as people have used language in transmitting ideas or propositions to express a certain feeling for others to know. Consequently, learning language requires learning about social and cultural background of language in each country as well. At the present, the world is in the midst of globalization. Using language alone to communicate would no longer be sufficient to keep one well-informed about thing. There is a need then for people to learn additional foreign languages for the communication for various objectives. They should also need to use language to search for knowledge and make themselves understand about way of life, tradition, and culture of people from other cultural and linguistic backgrounds to gain mutual understanding and co-exist in a peaceful way. Consequently, the need to learn more than one language has increased. Similar observation was also made by Prasitratthasin, Amara (1999, p. 14), who said that, in the present world, it is hard to find a monolingual society as the communication could now conveniently made, not like in the past. People in the society, then, have opportunity to contact with those outside their society and learn language and culture of others.

Thai language is a language interesting to many foreigners and enjoys popularity in the countries in Asian region and western countries. Though Thai language is not a universal language but, at the present, many more foreigners have come to learn Thai as a foreign language due the political, economic, business, tourism, education, etc. Teaching Thai as a foreign language both in Thailand and foreign countries get wide popularity. 
Concerning this, Witayasakpan, Sompong (2006, p.1) had pointed out the status and role of Thai language had changed. Presently, many foreigners had seriously and formally studied Thai language. The learners of Thai language were no longer limited only to Westerners but also Eastern ones and those from neighbouring countries. Quite a lot of them have been interested in study Thai language. Moreover, results of the survey carried out by the Division of Foreign Relations, Office of the Permanent Secretary, Ministry of foreign Affairs, in 2001, reveal that, at the present, more than 100 higher education institutions in Asia, Europe, United States, and Australia, have offered the program on Thai language or Thailand such as Asian Study, Southeast Asian Study, etc. In Thailand, there are more than 25 higher education institutions both of private and public ones had offered the program on Thai language for foreigners )Sathiansukon, Sureewan, 2011, p.129).

At the present, the provision on Thai language instruction for foreigners is a main task of higher education institutions both of the government and private ones. Concerning this, Ponmanee, Sriwilai )2002, p.15) had discussed about teaching Thai as a foreign language and had concluded that, from the survey by of Ministry of Foreign Affairs, it was found that there are many higher education institutions almost all over the world, had offered the study program on Thai language or other programs concerning Thailand totaling 114 institutions in Asia, Europe, America, and Australia. There is a trend of have more institutions to do so. Universities in Thailand and foreign countries have widely been interested in offering the program on Thai as a foreign language. Similarly, Bunthip, Akara )2012, p.9), faculty member from departments of Thai language and Eastern Asian language, Srinakharinwirot University, had stated that, at the present, world had come up the age of globalization. Many universities in foreign countries had widely offered the Thai major program or as a selective course. This might be due to the fact that, in Southeast Asia, Thailand is the country with secure economy and more stability than other neighboring ones. Consequently, businessmen from many countries had increasingly come to invest in the country. Besides, the cost of living in Thailand is not too high leading many investors from Japan, Korea, or China coming in to invest and start up industry in Thailand. When these entrepreneurs have invested in Thailand, they have to send their people to come to manage the business too. They have realized that their personnel have to communicate with Thai people. That's why there is a need for them to learn Thai language. The interest in Thai language has spread out both in Thailand and foreign countries. Similar observation was also made by Kosashunhanan, Krishna (2016, p.149) who informed that, at the present, many foreign companies came to invest in Thailand. From the data source, it was found that the amount of investment by Japanese in Thailand was about 3.6\% of the Japanese investment all over the world. Considering the request for investment supports submitted to the Board of Investment (BOI), it was found that Japanese investment was the highest amount among all the foreign investments.

It is apparent that the technological expansion and progress could help facilitate education and promote economic growth resulting Thai language becoming a language having role and significance in communication. Consequently, Ministry of University Affairs had the policy to support and widely spreading Thai language. From the data collected on foreign students studying in higher education institutions affiliating to the Office of Higher Education Commission, in 2012, )Bureau of International Cooperation Strategy, 2010(, it was found that, during 2008-2012, the fields mostly taken by foreign students coming in to study in Thai higher education institutions were business administration )11.85\%( followed by Thai language )5.81\%(, international business )5.38\%(, Thai language for communication )3.21\%(, and marketing )2.74\%(, respectively. Considering number of students along the country they are from, it reveals that foreign students coming from China the most (7.45\%) followed by South Korea )6.32\%(, Japan )6.22\%(, Vietnam (5.81\%(, Singapore $(5.81 \%$ (, and Myanmar $(0.41 \%$.

Teaching Thai as a foreign language in Thailand has progressed more. Faculty of Education, Chiang Mai University, is an institution having been in contact with many foreign agencies for a long period of time. Developing academic cooperation with other institutions and agencies at university and faculty levels has led the foreign relation operation to carry out the academic collaboration, searching from budget support, exchanging 
personnel and students with foreign institutions, and serving as an operational unit in providing information on personnel of Faculty. The program on teaching Thai language and culture has been offered for a long period of time for foreign students and foreigners who are interested in studying Thai language and culture. Particularly, every year, there would be a number of Japanese students coming in to learn Thai language and culture at the Faculty leading to the collaboration between the Faculty of Education and universities in Japan such as Shiga University, Kyoto Seika University, Keisen University, Kanda University of International Studies, Kokushikan University, Kanazawa University, for example.

The program on teaching Thai language and culture for Japanese students along the collaborative project on student exchange between Faculty of Education, Chiang Mai University, and various universities in Japan has been continuously operated every year. The programs include studying Thai as a foreign language both of shortcourse training and long-term curriculum for individual or group. However, the change and development in various aspects of the present world society have affected the study system and program including acceptance of foreign students into the programs. There are less and uncertain number of foreign students including Japanese students desiring to learn Thai language and culture at the Faculty compared with those in the past. This might have been the consequence of competition in offering Thai language teaching program for foreigners in higher education institutions both of private and public institutions in Thailand. There are many of them with variety of study program which are up-to-date, applicable, and could be used to maintain career in the future such as Thai language for business, Thai language for tourism, for example. Moreover, as their study program and instructional method are more interesting, modern, utilizing new instructional technology and media for teaching Thai language foreigners, location of the university which is convenient and facilitative for learning, and cost of the study, etc., they could attract more students. The researcher, as a teacher and a personnel who is responsible for teaching Thai as a foreign language for foreign students at the Faculty of Education, Chiang Mai University, has become interested on the issue and in conducting the research the needs for learning Thai language and culture of Japanese students studying Thai language at the Faculty. The data obtained from the research could inform about the problems and mistakes, including how to improve and develop the plan for each aspect of the program to maintain higher quality and efficiency to upgrade the quality of instruction and learning of Japanese students, and those from other countries.

\section{Objectives}

To study the needs for learning Thai language and culture of Japanese students coming in to study Thai language at the Faculty of Education, Chiang Mai University

\section{Research Process}

\section{Population and Sample}

The research population is of Japanese students coming to learn Thai language in universities in Thailand. The sample used the research was purposively selected from Japanese students coming to study Thai language and culture at the Faculty of Education, Chiang Mai University, in 2019 academic year from 2 universities - 23 from Kokushikan University and 23 from Kanda University of International Studies, totaling $\mathbf{4 6}$ subjects.

\section{Research Instrument}

Instrument for collecting data are the questionnaire asking about learning needs Thai language and culture of Japanese students studying Thai language at the Faculty of Education, Chiang Mai University, coming up in form of 5 level rating scale along Likert model, a questionnaire having been validated by 3 experts before improving it. The questionnaire covers 7 aspects, namely, 1) reason for studying Thai language at Faculty of Education, Chiang Mai University, 2) objectives of learning Thai language and culture, 3) learning contents, 4) 
instructional organization, 5) instructional media and equipment, 6) instructional measurement and evaluation, and, 7) other supports for promoting the student's learning Thai language and culture.

\section{Data Collection}

In collecting data, the researcher as the instructor for Japanese students coming to learn Thai language and Thai culture at the Faculty of Education, Chiang Mai University, in 2019 academic year from 2 universities Kokushikan University and Kanda University of International Studies, each of which with 23 students totalling 46 subjects. The researcher had distributed the questionnaire to each of them in the final class on the instruction.

\section{Data Analysis}

The quantitative data were analysed by descriptive statistics coming up with percentage, mean, and standard deviation.

\section{Research Outcomes}

Results of the research on needs for learning Thai language and culture of Japanese students coming to study Thai language at the Faculty of Education, Chiang Mai University, could be could be concluded as follows:

Part 1 General information of students who had responded to the questionnaire asking about learning needs Thai language and culture of Japanese students studying Thai language at Faculty of Education, Chiang Mai University is as follows:

Table 1 Number and Percentage of Japanese Students Studying Thai Language at the Faculty of Education Chiang Mai University Responding to the Questionnaire Asking about their Needs in Learning Thai Language and Culture

\begin{tabular}{llll}
\hline No. & Gender & No. of Subjects & Percentage \\
\hline 1 & Male & 21 & 45.70 \\
\hline 2 & Female & 25 & 54.30 \\
\hline & Total & 46 & 100.00 \\
\hline
\end{tabular}

Table 1 shows number, percentage, and gender of Japanese students responding to questionnaire asking about their needs for learning Thai language and culture as follows:

1) There were $\mathbf{2 5}$ female students or $\mathbf{5 4 . 3 0 \%}$ of the whole group.

2) There were $\mathbf{2 1}$ males students or $\mathbf{4 5 . 7 0 \%}$ of the whole group.

Table 2 Number and Percentage of the Japanese Students Responding to the questionnaire Asking about Needs for Learning Thai language and culture Classified by Age

\begin{tabular}{llll}
\hline No. & Age & No. of Subjects & Percentage \\
\hline 1 & 19 years old & 27 & 58.70 \\
\hline 2 & 20 years old & 15 & 32.60 \\
\hline 3 & 21 years old & 2 & 4.30 \\
\hline 4 & 22 years old & 2 & 4.30 \\
\hline
\end{tabular}


Proceedings of the International Conference on Future of Education, Vol. 2, Issue 2, 2019, pp. 1-12

\begin{tabular}{llll}
\hline 5 & 23 years old & 0 & 0 \\
\hline Total & 46 & 100.0 \\
\hline
\end{tabular}

From Table 2, number and percentage of Japanese students responding to the questionnaire asking about their needs for learning Thai language and culture reveal the age group along the percentage as follows:

1) There were 27 students who were 19 years old (58.70\%).

2) There were 15 students who were 20 years old (32.60\%).

3) There were $\mathbf{2}$ students who were $\mathbf{2 1}$ years old (4.30\%).

4) There were 27 students who are were 22 years old (4.30\%).

5) There were no student who was 19 years old $(0 \%)$.

Table 3 Number and Percentage of the Japanese Students Responding the Questionnaire Asking about Their Needs for Learning Thai language and Culture Classified by Their Year

\begin{tabular}{llll}
\multicolumn{2}{c}{ of Study } & & \\
\hline No. & Year of Study & No. of Subjects & Percentage \\
\hline 1 & First Year & 27 & $58.70 \%$ \\
\hline 2 & Second Year & 14 & $30.40 \%$ \\
\hline 3 & Third Year & 5 & $10.90 \%$ \\
\hline 4 & Forth Year & 0 & $0 \%$ \\
\hline & Total & 46 & $100 \%$ \\
\hline
\end{tabular}

From Table $\mathbf{3}$ - number and percentage of students by year of study responding to the questionnaire asking about learning needs Thai language and culture of Japanese students studying Thai language at Faculty of Education, Chiang Mai University. The results ranked along the number of students by year of study are as follows:

1) 27 first year students $(\mathbf{5 8 . 7 0} \%)$

2) 14 second year students $(\mathbf{3 0 . 4 0} \%)$

3) 5 third year students $(\mathbf{1 0 . 9 0} \%)$

4) 0 fourth year students $(\mathbf{0} \%)$

Part 2 - Data from the questionnaire asking about the needs for learning Thai language and culture of Japanese students studying Thai language at the Faculty of Education, Chiang Mai University, could be summarized as follows:

Table 4 Number, Percentage, Mean, and Standard Deviation and Interpretation of the Opinion of Students Having Responded to Questionnaire asking about the needs to Study Thai language and Culture of Japanese Students Studying Thai language at Faculty of Education, Chiang Mai University on 7 Aspects 


\begin{tabular}{lccc}
\hline Aspects & Mean & S.D. & Level \\
\hline $\begin{array}{l}\text { 1. Reason for studying Thai language at Faculty of Education, } \\
\text { Chiang Mai University }\end{array}$ & 4.39 & 0.22 & much \\
\hline 2. Objectives of studying Thai language and culture & 3.98 & 0.51 & much \\
\hline 3. Learning contents & 4.57 & 0.25 & Most \\
\hline 4. Instructional organization & 4.31 & 0.20 & much \\
\hline 5. Instructional equipment and media & 4.13 & 0.65 & much \\
\hline 6. Instructional measurement and evaluation & 4.18 & 0.28 & much \\
\hline 7. Facilitation for learning Thai language and culture of students & 4.29 & 0.35 & much \\
\hline Total & 4.26 & 0.19 & much \\
\hline
\end{tabular}

Table 4 displays number, percentage, mean, and standard deviation, and level of the opinions of the students having responded to the questionnaire asking about their needs for learning Thai language and culture of Japanese students studying Thai language at the Faculty of Education, Chiang Mai University of all 7 aspects revealing that, in general, the opinion was at much level with $\mathbf{4 . 2 6}$ mean and 0.19 standard deviation. When ranking by the mean from most to the least, the result is as follows:

1) Learning content is at most level with 4.57 mean and 0.25 standard deviation.

2) Reason for coming to study Thai language at Faculty of Education, Chiang Mai University is at much level with 4.39 mean 0.22 standard deviation.

3) Instructional organization is at much level with 4.31 mean and 0.20 standard deviation.

4) Facilitation for learning Thai language and culture of students is at much level with 4.29 mean and 0.35 standard deviation.

5) Instructional measurement and evaluation is at much level with 4.18 mean and 0.28 standard deviation.

6) Instructional equipment and media is at much level with 4.13 mean 0.65

standard deviation.

7) Objectives of studying Thai language and culture is at much level with mean 3.98 standard deviation 0.51

\section{Conclusion and Discussion}

First of all, from the research finding concerning the needs for learning Thai language and culture of Japanese students studying Thai language at Faculty of Education, Chiang Mai University, in all 7 aspects, it is found that, in general, it is at much with 4.26 mean. Ranking from the most to the least, it comes up as follows - 1) learning contents is at most level with 4.57 mean, 2) Reason for studying Thai language at Faculty of Education, Chiang Mai University, is at much level with 4.39 mean, 3) Instructional organization is at much level with 4.31 mean, 4) Facilitation for learning Thai language and culture of students is at much level with 4.29 mean, 5) Instructional measurement and evaluation is at much level with 4.18 mean, 6) Instructional equipment and 
media is at much level with 4.13 mean, and 7) Objectives of studying Thai language and culture is at much level with 3.96 mean.

From the results reported above, it could be discussed that the Japanese students who came to study Thai language and culture at the Faculty of Education, Chiang Mai University, put their focus on the learning contents and rated it at most level compared to other aspects. When putting into details of their needs, the first 3 of them are - 1) the needs to learn Thai language on the things close on the learner's life and usable in various situation is at most level with 4.80 mean, 2) the needs to have skills in Thai language - listening, speaking, reading, and, writing, is at most level with 4.76 mean, and, 3 ) the needs to learn Thai language vocabulary on various sections at most level with 4.67 mean. From all these data, it is found that teaching Thai as a foreign language for Japanese students or other foreign learners, the most important things to do are preparation, selection and planning for the contents to be taught. The contents should be significant for the individual's life and should promote the use of Thai language in everyday life communication. This is congruent to Buranasinvattanakul, Kingkarn (1975, p.176) who contended that in teaching Thai language for communication for foreigners learning Thai language, the teacher should be concerned with the learner's learning goals as at the end of each lesson, the learners should be able to use the language having learned to communicate or do other things. Thus, the organization of the contents of the lesson should be relevant to real communication in everyday life along the context of Thai society. The learners should be encouraged to connect the lesson to real situation which would enhance the effectiveness of the instruction on Thai language the foreign learners who are studying Thai language. Similar contention is also made by Buranapatana, Maliwan )2016( who stated that in developing the instruction on teaching Thai as a foreign language, the curriculum should be up to date and situation relevant to needs of the learners and world reality. In teaching Thai as a foreign language for any objectives such as for daily life usage, business, or carrying out a career, it is important that the learners should be enabled to use Thai language in effectively communicating. Consequently, in teaching Thai as a foreign language for 21 st century which is the age of information, the curriculum that could well satisfy needs of the learners should be conducted along the learner-centered approach. It should utilize the learning process that opens for the learners to really practice to learn by themselves via variety of learning processes and acquire skills for using the language to effectively communicate.

Firstly, Japanese students still needed to learn in the aspect of Thai language, namely, listening, speaking, reading, and writing. In preparing for the contents and instruction for the lesson, the teacher should not forget that teaching Thai as a foreign language teach the language skills along cultural insertion in relevant to the learning level of the learners to open opportunity for them to practice every skill for using Thai languagelistening, reading, speaking, and writing skills in integrative way to enable them to correctly communicate with Thai people in relevant to the social context and the needs of students. If was found that Japanese students had the needs to learn Thai language vocabulary in various sections at most level as well. It could imply that the students have needs to learn Thai language for the study. Learning vocabulary could enable them to learn the contents and really use the language for enhancing their capacity in communicating, studying, and working that requires Thai language usage to assure it effectiveness. Concerning this, Petcharat, Thamonpawee (2012, p.54) had pointed out the significance of vocabulary learning that it was significant for learning vocabularies of the disciplines being studied. Learning vocabularies could help the learners to increasingly understand the contents of the subject being studied.

Secondly, when reviewing the needs for learning Thai language and culture of Japanese students who are studying Thai language at Faculty of Education, in the aspect of the learning objectives, it was found that, in general, the needs was at much level with 3.98 mean. The first 3 needs were 1) the preference and interest in learning Thai language and culture was at most level with 4.57 mean, 2) the needs to learn Thai as another language was at much level with 4.37 mean, and, 3) the needs to learn Thai language because it was a significant, useful, and interesting much level with 4.04 mean. From such results, it could be apparent that Japanese students had the first objective of coming to study Thai language was that it made them prefer and 
interested to study Thai language and culture. They had been certain that Thai language was a language which was significant, useful, and interesting. Concerning this, Tiptiempong, Kosit (1975) had stated that new generation of Japanese had tended to choose to study Thai language because it is a Southeast Asian language gaining popularity among Japanese. Comparing the popularity, it would be found that Thai language is popular along with Vietnamese and Indonesian languages. In dealing with the student's decision, there is an interesting trend of rationality. Among previous generation, Japanese students made their decision in relation to the large number of Japanese companies in Thailand, Thai food, and traditional culture. Later on, however, their reasons vary. Many young Japanese would now like to learn about Buddhism in Thailand, education, as well as the English language teaching in Thailand.

Besides, Japanese students have another reason for studying Thai language and culture. They would like to learn another language besides Japanese and Thai language is the choice. They foresee that learning another new language would increase their opportunity in getting the job. Learning another language besides mother language could open for them to acquire the skills required for 21st Century. The students should acquire another language to serve as the door for interpersonal communication among people of the same nationality or foreigners. Language could facilitate people to gain common understanding among themselves leading to a more effective workplace. Besides, language could also serve as a passport for challenging opportunity and learning in their working life. From all these reasons, there is a need to be informed about the needs for studying Thai language and culture of Japanese students presently studying Thai language at Faculty of Education, Chiang Mai University, in the aspect of their objectives to learn Thai language and culture. The results would be useful for organization each instruction. The teacher should be well informed about the objectives or goals of learning as well as prior knowledge before they could design the instruction for each class in an appropriate way to achieve the goals of learning Thai as a foreign language of the learners.

Thirdly, concerning the needs for learning Thai language and culture of Japanese students studying Thai language at Faculty of Education in Issue 4-instructional organization, it was found that the outcome in general was at much with 4.31 mean. When each aspect was considered, it was found that Japanese students had the needs on each issue such as needs for variety of instructional methods not just lecturing, needs for participating in the instruction, and had a lot of opportunity to practice the language, needs for using games, songs, or activities to involve the students into practice, needs for books or instructional materials that were easily understandable, clear, and not complex, etc. From all these data, the teacher teaching Thai as a foreign language for foreign learners should well understand the psychological principle of instruction and instructional activity organization to facilitate the learners to learn Thai as a foreign language in joyful way, having confidence in using Thai language, having good attitude towards studying Thai language, and succeeding in the learning to be able to communicate the along the goals set. This contention is congruency with the thought of Tran $\mathrm{Cam} \mathrm{Tu}$ 2016, p.16) who proposed the approach to teach Thai language Hanoi University students. He recommended that the method of teaching language should be applicable not solely focus academic contents. Students should be enabled to apply what they have learned in communicating with the target group of people and in carrying out their career in effective way. The instruction should take into consideration the characteristics and mental model of the learners. In teaching, the teacher should build up atmosphere of Thai culture and society to serve as the environment to facilitate the learners internalize the language. The teacher should make Thai language instruction easy to motivate the learners to learn and to be assured that what they learn from the classroom could be really used in their real life. Thai language classroom should be full of joy creating fun from learning with the language owner. Similar contention was also made by Witayasakpan, Sompong )2006, p.113) who proposed the model for teaching language as a foreign language citing 9 basic principles to lead to the success. There are 1) knowing the learners, 2) number of the learners, 3 3) duration for the instructional organization, 4) constructing appropriate curriculum, 5) creating appropriate lessons, 6) creating effective instructional and learning media, 7) inventing teaching strategy and classroom activities, 8) organizing outside classroom learning activities, and, 9) measuring and evaluating. Besides, Witayasakpan, Sompong )2006, p.132) also recommended 
that in teaching language and culture for foreigners, one should come up with the lessons which were interesting, easily memorable, joyful, satisfying the interests of the learners, suitably long, having not to many vocabularies, with exercise utilizing short and communicable statements and immediately applicable, etc. The textbook contained Thai way of life could interest the foreign learners to desire to learn by themselves and review their learning at the end of every class.

Lastly, in analysing the needs for learning Thai language and culture of Japanese students studying Thai language at the Faculty of Education in Aspect 7 concerning what to facilitate Thai language and culture learning of the students, it was found that, in general, the outcome was at much level with 4.29 mean. When considering by sub-aspects, it was found that the sub-aspect gaining the needs at most level was the needs for the activities to promote more understanding on Thai culture, society, and people, such as eating Thai food, going to the temple, performing Thai dance and Thai boxing, all were at most level with 4.70 mean. The needs for getting to know Thai student buddy was at most level with 4.63 mean. The finding could be further discussed that teaching Thai as a foreign language for Japanese students or other foreign students is the language instruction in form of cross-cultural communication. The students could learn Thai language and culture in an understandable and applicable ways. It is important that the students have to learning Thai language along with Thai culture. Thus, teaching Thai language is related to cross-cultural communication. It is important and necessary to language for cross-cultural communication with people with different language, nationality, and culture. It is difficult to avoid such phenomena at the present time. Moreover, Learning Thai as a foreign language and using Thai language for cross-cultural communication require the learners and language users to study, understand, and accept similarity and difference of cultures. This is congruent to the contention made by Bakhtin )1981, p.45( who stated that learning and developing a language were the results of interaction of language and culture in the society. Every word or act is taken as the expression on language and culture. Similarly, Tseng )2002, p.31( had stated that culture occurred while the learners got involved with the learning process and cross-cultural communication. Besides, Brown )2000 cited in Hiranpat, Pattaraporn, 2005, p.89) had explained that, as culture was a model of behavior and process deeply set in people's mind, it was very much necessary for learning a second language. As language and culture were interrelated, learning the second language would automatically include learning the second culture as well. Similarly, Phonlabutra, Kamolthip 2013,p.102) had studied the guideline for teaching and learning between cultures for Thai students studying Japanese as a foreign language. The author proposed the guideline for teaching and learning between languages and cultures covering 1) language and culture topics, 2) instructional methods and media for teaching language and culture, and, 3) factors of teaching and learning between language and culture which included objectives and learning activities, evaluation on skills and knowledge, and factors on researching and developing on the model for learning between language and culture. It could be concluded that the learners who were Japanese students had the concepts and beliefs that culture is the significant factor of learning a language.

It is apparent that what to well facilitate learning Thai language and culture of Japanese students is that the Japanese students have to have good friendship (Buddy) with Thai students. From experiencing classroom instruction on Thai language of foreign students, the researcher has found that most students are undergraduate students aging at teen and early adult period. They need to have friends and get together in talking and exchanging ideas, feeling, and experiences. Besides contacting with the teacher, the Japanese students or other foreign students have to have Thai friends to build up friendship, learn about being Thai, and have chance to practice and use Thai language with those Thai friends. Similar contention was also made by Chotivachira, Boonrawd (2016, p.153) who had pointed out about the model of cross-cultural education for teaching Thai as a foreign language at undergraduate level of universities in Thailand and Republic of South Korea on the instruction that was successful in enhancing the learner's Thai language skills via peer assist technique along with Thai buddy. Similarly, Hung (1985, p.21( had found that learning language in the real situation and think in Thai language, having conversation with the teacher and owner of the language whenever time comes is very important. 
From the above reviews, the researcher had obtained the information on opinions of Japanese students on various issues concerning the needs to learn Thai language and culture of Japanese students who took the course in Thai language at Faculty of Education, Chiang Mai University. Their opinions came up in 7 issues, namely, 1) reason for taking Thai language course at the Faculty of Education, Chiang Mai University, 2) objectives of studying Thai language and culture, 3) learning contents, 4) instruction, 5) instructional equipment and media, 6) instructional measurement and evaluation, and, 7) things to facilitate the study on Thai language and culture of students. These 7 set of information could serve as the guideline for organizing instruction to teach Thai language as foreign language to the Japanese learners and the learners from other countries. This is a crucial factor to enhance the learner's understanding via communication across culture. Language is the medium for interpersonal communication of the individuals from different language, society, and culture leading to learning society. The concerned individuals have more realized the significance of creating interlingual and intercultural understanding enabling them to learn language and culture leading to their cultural understanding and selfadjustment across culture resulting friendly co-existence. This conceptual framework could be able to help upgrade the quality of organizing the program in teaching Thai as a foreign language of Faculty of Education, Chiang Mai University to assure better success.

\section{Recommendations}

\section{Recommendations for Instruction}

Universities or other higher education institutions running the study programs on teaching Thai as a foreign language for Japanese students could apply the findings from this research to develop their study program on teaching Thai as a foreign language to assure the acceptable quality and benefits to the educational institutions both in Thailand and the foreign countries in the future to come.

Universities or other higher education institutions running the study programs on teaching Thai as a foreign language for Japanese students could review, realize, and recognize the significance of the instructional content preparation, instructional activities, instructional techniques, learning resources, instructional media, measurement, and evaluation including the characteristics and roles of the teacher to satisfy the needs and interests the learners and keeping up to the change of the world society.

Universities or other higher education institutions offering the teacher training program and instruction on teaching Thai language as a foreign language for foreign students should design the instruction to integrated Thai culture to Thai language. Beside paying attention to the classroom instruction, the students should be encouraged to get involved with outside activities on language and culture to open opportunity for them to learn get in touch with culture and learn Thai language through it. They should have experience in getting in touch with Thai language in the societal context having direct and collective experiences in exchanging language and culture with the language owners.

There should be some seminars for exchanging learning on various issues among the administrators, teachers, students, and academics or others who are concerned with learning and teaching Thai as a foreign language of universities or other higher institutions in Thailand and foreign countries to offer the study program on teaching Thai as a foreign language.

\section{Recommendations for Further Research}

There should be some studies on the needs for studying Thai language of the students from each country coming up to study Thai as a foreign language in various faculties of Chiang Mai University. 
There should some studies on policy or approach in offering study program on teaching Thai as a foreign language comparing between universities in Thailand and those in the foreign countries.

\section{References}

In Thai

Bunthip, Akara. )2012(. Thai Language Market Bloom-Foreigners becoming Interested to Learn.

[Online system]. Source: news.swu.ac.th/newsclips/doc/20061402.doc.

Buranapatana, Maliwan. )2016(. "Learning and Teaching Thai as a Foreign Language in 21st Century." Materials for International Seminar on 50th Anniversary of Establishing Thai Language Department, Hankuk University of Foreign Studies and Foreign Language and Affairs, Republic of South Korea, 27 October 2016.

Bureau of International Cooperation Strategy. )2010(. Strategy for Thai Higher Education in Being Prepared to Enter ASEAN Community in 2015. Bangkok: Bangkok Block.

Buranasinvattanakul, Kingkarn. (1975). "Method for Teaching Thai for Communication for Students Studying Thai as Foreign Language." Ubon Ratchathani University Journal of Liberal Arts, Vol. 18, No. 2, JulyDecember, 1975.

Chotivachira, Boonrawd )2016). Cross-cultural Model for Teaching Thai a Foreign Language at Undergraduate Level of Universities in Thailand and Republic of South Korea. Doctor of Education Dissertation, Higher Education Program, Department of Educational Management Policy and Leadership, Faculty of Education, Chulalongkorn University.

Hiranpat, Pattaraporn. )2005(. "Cross-cultural Communication and Second Language Teaching. Language and Culture Journal, 24 January-June 2005 No. Kosashunhanan, Krishna. (2016). "Using English for Communication of Thai Engineers: The Case of Japanese Companies in Amata Nakorn Industrial Estate." Dhurakij Pundit University Suthiparithat Journal, Vol. 30, No. 93, January-March, 2016. (pp.146-159).

Petcharat, Thamonpawee. (2012). Surveying the Needs for Using English to Assess the Materials for Training English for Offshore Petroleum Staff. Study Program on English as International Language.

Phonlabutra, Kamolthip. )2013(. "Instructional Guideline for Cross-cultural Learning of Thai Students Studying Japanese a Foreign Language." Journal of Humanities and Social Sciences, Vol. 5, No. 2, JulyDecember, 2013.

Ponmanee, Sriwilai. )2002(. Foundations of Teaching Thai as a Foreign Language. Bangkok: Chulalongkorn University Press.

Prasitratthasin, Amara. (1999). Sociolinguistics. Bangkok: Chulalongkorn University Press.

Sathiansukon, Sureewan. (2011). "Teaching Thai language to Chinese Students: Currents Conditions, Problems, and the Solution." Humanity Journal, Faculty of Humanity, Kasetsart University, Vo. 18, No. 1 ,

Tiptiempong, Kosit. (1975). "Why do new generation of Japanese come to choose "Thai

Study?" Japan In-depth column. Online system]. Source: www.mgronline.com )23 April, 1975(.

Tran, Cam Tu )2016(. "Techniques for Teaching Thai to Vietnamese Students at Hanoi University", Documents for the 3rd National Seminar on Teaching Thai Language in Asia, 30-31 May, 2016, at The Emerald Hotel, Bangkok.

Witayasakpan, Sompong. )2006(. Teaching Thai as a Foreign Language. Chiang Mai: Ming Muang Printing. 
Boonrawd Chotivachira /A Study of the Needs for Learning Thai language....

In English

Bakhtin, M. M. )1981(. The Dialogic Imagination: Four Essays )M.Holquist, ed.; C.Emerson

\& M.)Hung, X.H. (1985). "Chinese EFL Students Language Strategies for Oral Communication." TESOL Quarterly. 19 )March 1985(: 167-180.

Tseng, Y. H. )2002(. “A Lesson in Culture.” ELT Journal, 56)1(, 11-21. 